
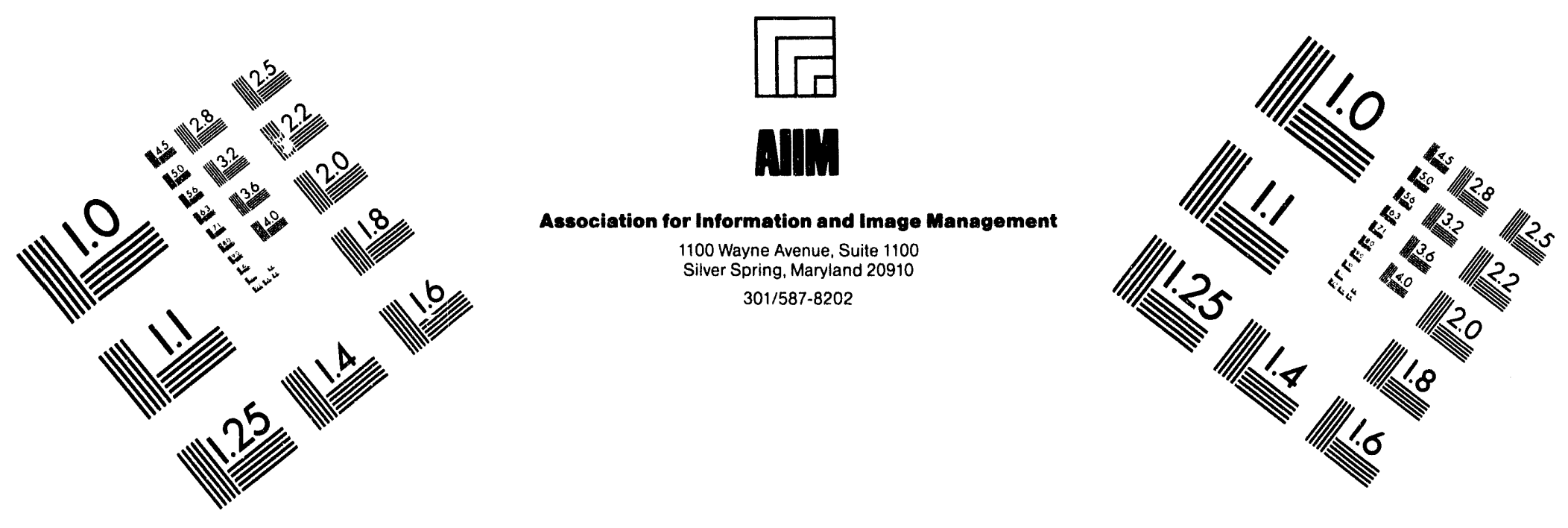

\title{
Centimeter
}

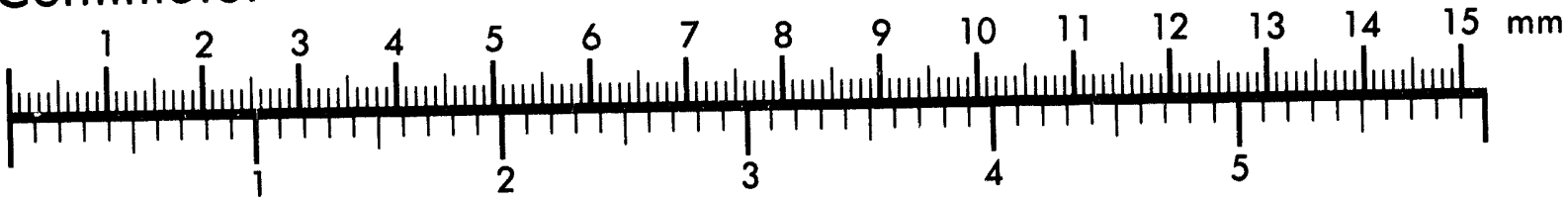
Inches

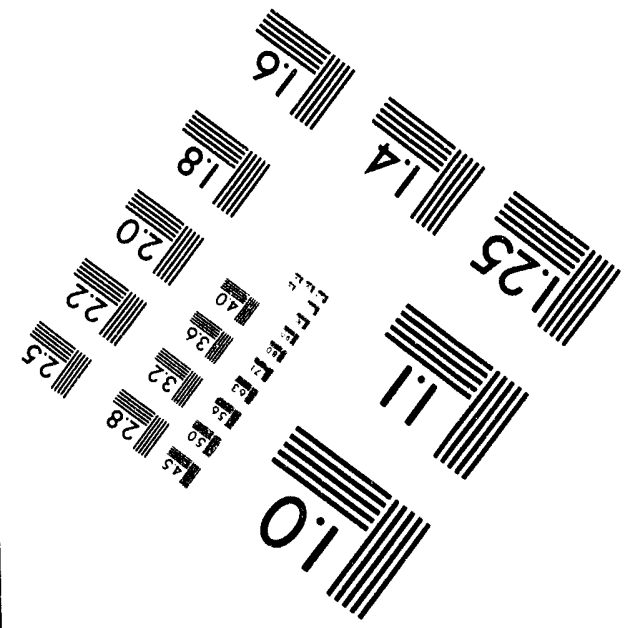

MANUFACTURED TO AIIM STANDARDS

$$
\text { BY APPLIED IMAGE, INC. }
$$

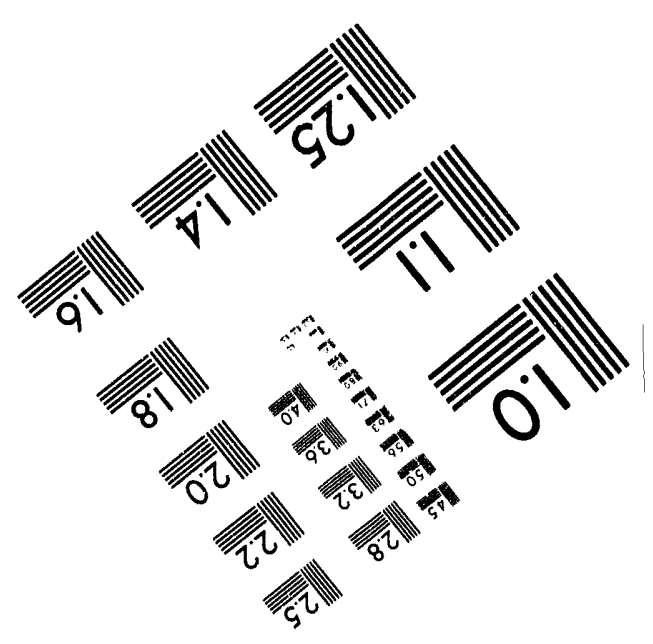



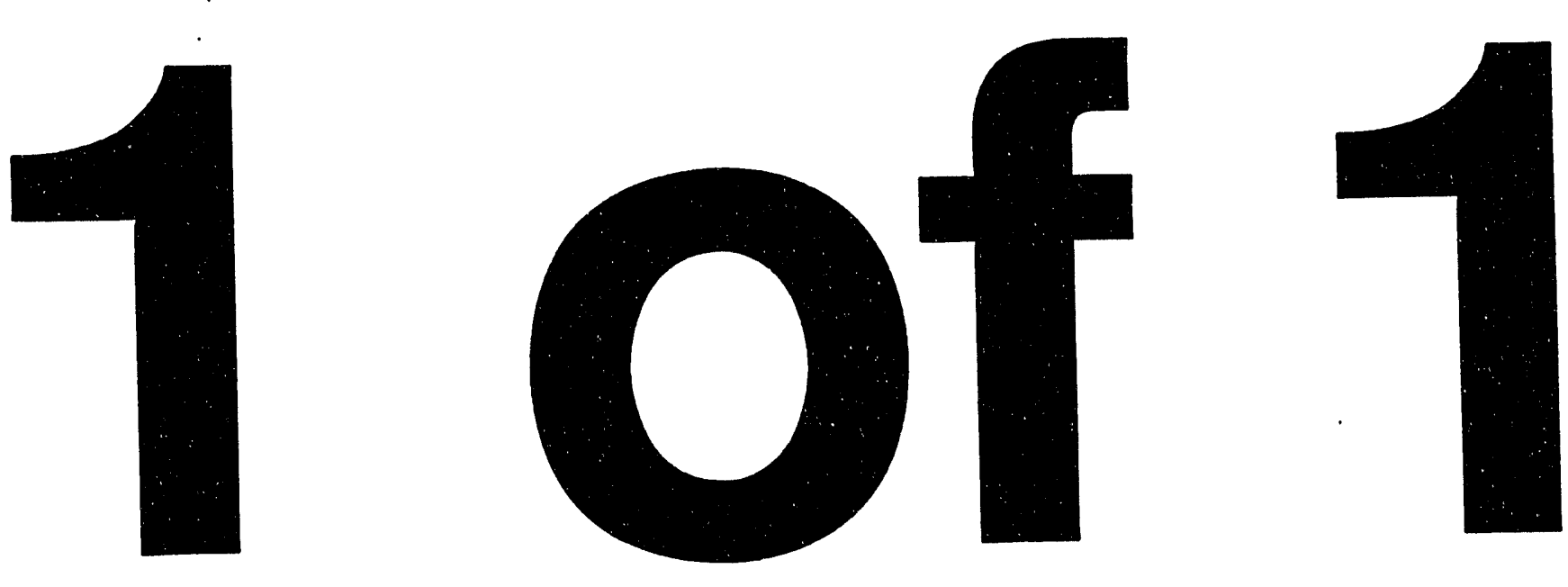


\section{WELDING IRRADIATED STAINLESS STEEL (U)}

by

W. R. Kanne, Jr.

Westinghouse Savannah River Company

Savannah River Site

Aiken, South Carolina 29808

G. T. Chander

D. Z. Nelson

E. A. Franco-Ferreira

A document prepared for JOURNAL OF NUCLEAR MATERIALS SYMPOSIUM ON EFFECTS OF IRRADIATION at Sun Valley, Idaho from 6/20/94 thru 6/23/94.

DOE Contract No. DE-AC09-89SR18035

This paper was prepared in connection with work done under the above contract number with the U. S. Department of Energy. By acceptance of this paper, the publisher and/or recipient acknowledges the U. S. Government's right to retain a nonexclusive, royalty-free license in and to any copyright covering this paper, along with the right to reproduce and to authorize others to reproduce all or part of the copyrighted paper. 


\section{DISCLAIMER}

This report was prepared as an account of work sponsored by an ageacy of the United States Govermmeat. Neither the United States Governmeat nor any agency thereof, nor any of their employees, makes any warranty, express or implied. or assumes any legal liability or responsibility for the accuracy, completeness, or usefulness of any information. apparatus, product, or process disclosed, or represeats that its use would not infriage privately owned rights. Reference herein to any specific commercial product, process, or service by trade name. trademark. manufacturer, or otherwise does not necessarily constitute or imply its endorsement. recommendation, or favoring by the United States Governmeat or any agency thereof. The views, and opinions of authors expressed berein do not necessarily state or reflect those of the United States Goverameat or any ageacy thereof.

This report has been reproduced directly from the best available copy.

Available to DOE and DOE contractors from the Office of Scieatific and Technical Information. P. O. Box 62. Oak Ridge. TN 37831: prices available from (615) $576-8401$.

Available to the public from the National Techaical Information Service. U. S. Deparmeat of Commerse, 5285 Por Royal Rd., Springfield. VA 22161 


\section{WSRC-MS- $93-6 / 9$}

WELDING IRRADIATED STAINLESS STEEL

W. R. Kanne, Jr., G. T. Chandler, D. Z. Nelson, and E. A. Franco-Ferreira

Westinghouse Savannah River Company, Aiken, SC 29808, USA

\section{Abstract}

Cónventional welding processes produced severe underbead cracking in irradiated stainless steel containing 1 to 33 appm helium from $n$, a reactions. A shallow penetration overlay technique was successfully demonstrated for welding irradiated stainless steel. The technique was applied to irradiated 304 stainless steel that contained 10 appm helium. Surface cracking, present in conventional welds made on the same steel at the same and lower helium concentrations, was eliminated. Underbead cracking was minimal compared to conventional welding methods. However, cracking in the irradiated material was greater than in tritium charged and aged material at the same helium concentrations. The overlay technique provides a potential method for repair or modification of irradiated reactor materials. 
WELDING IRRADIATED STAINLESS STEEL

\author{
W. R. Kanne, Jr., G. T. Chandler, D. Z. Nelson, and E. A. Franco-Ferreira \\ Westinghouse Savannah River Company, Aiken, SC 29808, USA
}

\title{
1. Introduction
}

The heat-affected zone (HAZ) of repair welds cracked when patches were welded to the tank wall of a nuclear reactor at the Savannah River Site. The cracking was caused by helium embrittlement [1]. Helium was present in the type 304 stainless steel reactor tank wail due to neutron capture by alloy and impurity elements. The mechanism for this embrittlement was attributed to the nucleation, growth and coalescence of helium induced microvoids during the welding process. Scanning and transmission electron microscopy showed the formation of small helium bubbles on grain boundaries in the steel and the presence of dimples on fracture surfaces [2,3]. Similar helium induced microstructures have been found in type 316 stainless steel samples that were welded after helium was introduced into the material [4,5]. Dimpled fracture is believed to result from bubble coalescence during a creep like fracture of the grain boundaries in the weld HAZ.

An experimental program was initiated to develop a repair technique that eliminated or at least minimized helium embrittlement cracking. About 30 different processes were considered from mechanical attachments to solid-state welding processes and laser surfacing. However, a fusion welding technique was determined to be the best option. In order to minimize cracking, the 
technique would need to minimize the stresses and temperature in the weld heat-affected zone.

A low-penetration gas metal arc (GMA) overlay technique was developed to fill this need [6]. This technique minimized heat input to the base material while providing sufficient weld penetration to develop a continuous metallurgical bond between the weld and base metal. The technique provided a weld weave to produce a $2.6 \mathrm{~cm}$ wide weld overlay that was approximately $0.9 \mathrm{~mm}$ thick. Type 308 filler wire was used for the welding process. Weld penetration into the base metal was approximately $0.08 \mathrm{~mm}$. This minimal penetration reduced the size of the heat-affected zone and high stress regions in the substrate material. Metal transfer to the overlay was by the short-circuit mode and high speed cross seam mechanical oscillation of the arc.

Application of low-penetration gas metal arc (GMA) weld overlay techniques provided encouraging results by producing a pronounced reduction in cracking compared to the repair welds in the reactor tank. Reduction in helium embrittlement cracking has also been obtained by Lin et al. $[7,8]$ by cold working, precipitate addition, and by application of compressive stress during welding.

Results from the extensive testing performed on tritium charged and aged material have now been compared with damage developed when similar welds were made on 304 stainless steel irradiated up to 18 appm helium. This paper summarizes results from the development program using helium introduced by tritium decay, presents results for both conventional and overlay welds on irradiated material, and compares the embrittlement developed in the two types of samples (tritium aged vs. irradiated). 


\section{Weld Process Evaluation}

Prior to welding on irradiated material, the effectiveness of the shallow penetration overlay welding process in minimizing helium embrittlement was demonstrated by' welding type 304 stainless steel plates that had been charged with tritium. Helium was produced in the plates by tritium decay, and the tritium was then removed by outgassing prior to welding. Plates were charged to predetermined helium contents between 3 to 220 appm (atomic parts per million). The helium content, confirmed by chemical analysis, was controlled by the tritium charging conditions (temperature, pressure and time) and the time for tritium decay. Overlay welds, along with gas tungsten arc (GTA) and gas metal $\operatorname{arc}(\mathrm{GMA})$ stringer beads, were made on the helium-containing plates.

\subsection{Crack distributions}

External surfaces of the welds were visually examined and penetrant tested for toe cracks (large surface cracks in the HAZ around the edge of a weld bead) and for porosity (gas bubbles in the weld metal that may be open to the surface or may be trapped within the weld metal below th surface). Helium in the base metal caused toe cracks to form from the agglomeration of small $(2-3 \mathrm{~nm}$ diameter) helium bubbles on grain boundaries and the weld induced coalescence of those bubbles to form an intergranular crack. The evolution of such a crack is shown schematically in Fig. 1. Porosity results simply from the macroscopic release of helium from the base metal during welding. Neither type of defect was found in welds on helium free plates. 
Surface examination of the welded helium charged plates revealed no toe cracks or porosity associated with the overlay welds. However, welds made by conventional GTA or GMA processes had both types of defects. Toe cracks for the highest heat input conventional welds were typical of those seen during repair of the reactor tank. Metallographic examination of test welds in tritium charged and aged stainless steel confirmed the lack of toe cracking in overlay welds compared to conventional welds (Fig. 2).

Helium induced cracks in all welds were totally intergranuiar. The underbead cracks were located in the $\mathrm{HAZ}$ of welds and did not generally intersect the material surface. Typically underbead cracks were smaller than toe cracks and were in a narrow, $2 \mathrm{~mm}$ band adjacent to weld metal. Occasionally, underbead cracks extended for a very short distance $(0.05 \mathrm{~mm})$ into weld metal.

The extent of cracking was assessed quantitatively as a function of base metal helium concentration, weld penetration, and type of weld. Cracking increased with helium concentration, as was expected. Quantitative metallographic analysis showed a substantial reduction in underbead cracking of the overlay welds compared to conventional GTA and GMA welding methods. This result, along with the elimination of toe cracks, is strong evidence for the advantages of the overlay technique for successful welding on helium-bearing material.

The effect of muitiple layer overlays was also determined. An additional practical advantage of use of overlays is the ability to build up multiple layers, should a thick overlay be needed for structural reasons. A second layer had a negligible effect on underbead cracking. 


\subsection{Mechanical tests}

Two test methods were used to evaluate the mechanical integrity of the weld overlay process on tritium charged and aged 304 stainless steel [9]. Tensile testing of the bond between the overlay and the base plate was used to evaluate the strength and ductility of the $\mathrm{HAZ}$ and of the interface between the overlay and the base plate. Bend testing was used to determine the effect of stress on existing helium embrittlement cracks.

Tensile tests of the overlay welds showed that strength and ductility are not compromised in samples containing up to about 35 appm helium in the tritium charged and aged material. The reduction of area decreased significantly for samples that contained over 35 appm helium. Coincident with this loss of ductility was a change in the appearance of the fracture surfaces. Scanning elefctron microscope analysis of the tensile samples showed that the failure mode changed from ductile dimple rupture in the base metal at low helium concentrations to brittle intergranular fracture of the underbead heat-affected zone at high helium concentrations.

Bend tests showed that helium embrittlement cracks do not propagate beyond the weld HAZ even under severe stress. Specimens were examined with a scanning electron microscope in the areas of uniform strain near the center of each specimen. At all helium levels cracking was intergranular and was restricted to the HAZ. The width of the cracks increased during bending but crack length was almost constant, demonstrating the localized nature of the helium embrittlement damage. 


\section{Evaluation of welds on irradiated stainless steel}

\subsection{Conventional welds}

Gas Tungsten Arc welds were made on 304 stainless steel irradiated with fluences of $1.0 \times 10^{21}$ to $3.8 \times 10^{21} \mathrm{n} / \mathrm{cm}^{2}$ thermal and $1.0 \times 10^{16}$ to $7.6 \times 10^{20} \mathrm{n} / \mathrm{cm}^{2}$ fast. Fast is defined as greater than $0.1 \mathrm{MeV}$. This irradiation resulted in measured helium concentrations from 1 to 18.6 appm helium. All irradiated material was from reactor tank walls at the Savannah River Site.

Helium induced weld cracks around conventional welds caused leaks during an attempt to repair the irradiated tank wall of a Savannah River reactor in 1986 and resulted in permanent shutdown of that reactor [1]. Welds made robotically in the reactor tank had surface toe cracking along with extensive underbead cracking. Dye penetrant testing of the welds in the reactor tank dramatically indicated the presence of the cracks. Electro discharge machining was used to remotely remove tank wall material containing the welds so that metallurgical examination could be performed. Helium concentration of this material was measured as $1.5 \mathrm{ppm}$, a result of the lowest thermal and fast fluences given above. Metallographic sectioning of the welds showed the extent of the intergranular cracking in the weld heat-affected zones, Fig. 3.

Gas Tungsten arc welds made on six inch diameter, 0.5 inch thick, discs core drilled from a reactor tank wall also cracked extensively. Weld cracks were similar in nature to those made in the reactor tank. High heat input welds caused more severe cracking than did low heat input welds. Welds made on 
discs with high helium concentrations cracked more than those made on discs with low helium concentration. This was particularly evident when comparing low heat input welds made on material of different helium concentrations. Oscillation of the welding arc and peening of the surface prior to welding appeared to reduce cracking, but results were not conclusive.

From this work it was clear that the amount of cracking when welding irradiated 304 stainless steel increased from both higher helium concentration in the metal and from increased heat input. This led to the effort to find a low heat input welding process that could be used on material with relatively high helium contents without the presence of surface toe cracking and only minimal underbead cracking. The overlay weld, whose development was described in the previous section, served this purpose. Application of the overlay weld to irradiated material is described in the next section.

\subsection{Overlay welds}

The applicability of the overlay technique to irradiated material was assessed by welding one of the six inch diameter discs from the wall of a Savannah River reactor tank. The radiation fluences to the inside surface of this disc were $2.6 \mathrm{x}$ $10^{21} \mathrm{n} / \mathrm{cm}^{2}$ thermal and $7.6 \times 10^{20} \mathrm{n} / \mathrm{cm}^{2}$ fast. This irradiation produced measured helium contents of 10.4 appm on the inside surface and 5.0 appm on the outside surface of the disc. The disc is $1.3 \mathrm{~cm}$ thick 304 stainless steel with a slight curvature due to the $4.9 \mathrm{~m}$ diameter of the reactor tank. An overlay weld approximately $7.6 \mathrm{~cm}$ long and $2.6 \mathrm{~cm}$ wide was made on each side of the disc (Fig. 4). Welding was performed remotely in a manipulator cell facility. 
Dye penetrant testing and metallographic examination of overlay welds on the irradiated disc showed no surface cracks. Metallographic sectioning of the edges of the overlay welds, Fig. 5A, confirmed the absence of toe cracks. Compare this to the conventional welds that resulted in deep surface cracks and underbead cracks (Fig. 3) in the heat-affected zone of welds even when the helium content was 3.3 appm or' less. The overlay method therefore avoids toe cracks, present in conventional welds made in irradiated material at much lower helium concentrations.

Analysis of the welds was completed by counting the number and length of cracks in metallographic sections of each overlay weld. Measurements showed approximately twice the amount of cracking beneath the overlay weld made on the material with $10.4 \mathrm{appm}$ helium as on the material containing $5.0 \mathrm{appm}$ helium. The area with the greatest concentration of cracks observed for the overlay welds is shown in Fig. 5. Cracks were observed in the weld heat-affected zone and, at several locations, these cracks extended into the weld metal.

The analysis demonstrated that the overlay technique is applicable to 304 stainless steel impregnated with helium by irradiation as well as by tritium decay. Surface cracking was eliminated and underbead cracking, although significantly greater than for tritium charged and aged material, was minimal compared to conventional welding methods.

\section{Comparison of implantation by tritium decay and irradiation}

The effect of helium on the weldability of stainless steel is expected to differ depending upon implantation technique for a number of reasons. Primary 
among these is the anticipated difference in distribution of the helium in the microstructure and the presence of other transmutation products in the irradiated material. Helium from transmutation of boron in the stainless steel matrix is expected to be in the grain boundaries due to the location of boron as an impurity element. On the other hand, helium from transmutation of nickel is expected to be distributed throughout the matrix. For tritium charged and aged material, helium is expected to be distributed throughout the matrix because of the high solubility of tritium in austenitic stainless steel. Additionally, damage to the metal matrix of irradiated material may play a part in the weld heat-affected zone crackirig, as may the presence of lithium from irradiation of boron. The overall effact of these differences was unknown until the present study demonstrated that the tritium aged samples were less susceptible to weld damage than the irradiated samples.

Cracking was minor in overlays made on the irradiated material, however, it was considerably higher than that experienced for the tritium charged and aged material at the same helium concentrations. This comparison of damage holds for both conventional welds, where measured crack lengths were 31 times greater in irradiated material compared to tritium charged and aged material, and for overlay welds, where measured cracks lengths were 28 times greater. These results are based on crack lengths at a helium concentration of 10 appm, Fig. 6. Crack length data for welds at a series of helium concentrations provide additional credence for results at 10 appm helium. Measurements of cracking on tritium charged and aged material are presented in more detail in reference [9]. Measurements for overlays on irradiated material are from the present work and measurements for conventional welds on irradiated material are from unpublished work at helium concentrations up to 12 appm. 


\section{Conclusions}

A low-penetration weld overlay technique, developed for repair of heliumcontaining materials, has been successfully applied to irradiated material. Elimination of large surface cracks, present using conventional welding methods, and reduction of underbead cracking was demonstrated on irradiated 304 stainless steel. This technique is expected to be a practical method for repair or modification of irradiated reactor components.

The overlay technique was developed on tritium charged and aged material prior to its application to irradiated material. Weld cracking is significantly higher for irradiated material than for tritium charged and aged material at equal helium concentrations.

\section{Acknowledgments}

The authors wish to thank D. T. Rankin and M. R. Louthan of the Savannah River Technology Center for their technical guidance throughout this study. Examination of GTA welds on irradiated material and mechanical testing of tritium aged material was done at the Westinghouse Science and Technology center in Pittsburgh, PA. Tritium charging and aging of test samples was done at Sandia National Laboratories in Livermore, CA.

This paper was prepared in connection with work done under Contract No. DEAC09-89SR18035 with the U. S. Department of Energy. 


\section{References}

1. W. R. Kanne, Ir., Welding Journal 67-8 (1988) 33.

2. W. R. Kanne, Jr., D. A. Lohmeier, K. A. Dunn, and M. H. Tosten, Materials Characterization 30 (1993) 23.

3. S. H. Goods and C. W. Karfs, Welding Journal 70-5(1991) 123.

4. H. T. Lin, S. H. Goods, M. L. Grossbeck, and B. A. Chin, Effects of Radiation on Materials: 14th International Symposium, Volume I, ASTM STP 1046, Eds. M. H. Packan, R. E. Stoller, and A. S. Kumar, American Society for Testing and Mąterials, Philadelphia (1989) p. 301.

5. H. T. Lin, M. L. Grossbeck, and B. A. Chin, Metallurgical Transactions A 21A (1990) 2585.

6. E. A. Franco-Ferreira and W. R. Kanne, Jr., Welding Journal 71-2 (1992) 43.

7. H. T. Lin and B. A. Chin, J. Nucl. Mater., 179-181 (1991) 1131.

8. C. A. Wang, H. T. Lin, M. L. Grossbeck, and B. A. Chin, J. Nucl. Mater., 191194 (1992) 696. 
9. W. R. Kanne, Jr., G. J. Bruck, A. Madeyski, D. A. Lohmeier, M. R. Louthan, Jr., D. T. Rankin, R. P. Shogan, G. G. Lessmann, and E. A. Franco-Ferreira, Proceedings of the Fifth International Symposium on Environmental Degradation of Materials in Nuclear Power Systems - Water Reactors (American Nuclear Society, 1992) p. 390.

Figure Captions:

Figure 1. Progression from helium bubble formation to grain boundary cracking during welding.

Figure 2. Comparison of cracking in welds made on tritium charged and aged 304 stainless steel containing 17 appm helium. Note the absence of cracking in the overlay.
A. Low penetration gas metal arc overlay weld.
B. Toe cracks in conventional gas tungsten arc weld.

Figure 3. Conventional gas tungsten arc weld on irradiated 304 stainless steel containing 1.5 appm helium.

Figure 4. Overlay weld approximately $7.6 \mathrm{~cm}$ long made on irradiated 304 stainless steel containing 5.0 appm helium.

Figure 5. Metallographic sections of low-penetration overlay welds made on irradiated 304 stainless steel containing 10.4 appm helium. Dark area on top is 
weld metal and light area in lower half is base metal including the heat-affected zone.

A. Edge location. Note the absence of toe cracking in the overlay weld.

B. Underbead at location of maximum cracking. Note that some cracks extend from the heat-affected zone into the weld metal.

Figure 6. Bar chart summarizing quantitative analysis of underbead damage due to helium embrittlement cracking of 304 stainless steel charged to $10 \mathrm{appm}$ helium. More cracking was measured for conventional welds than overlay welds. More cracking was measured for welds in irradiated material than in tritium charged and aged material. 


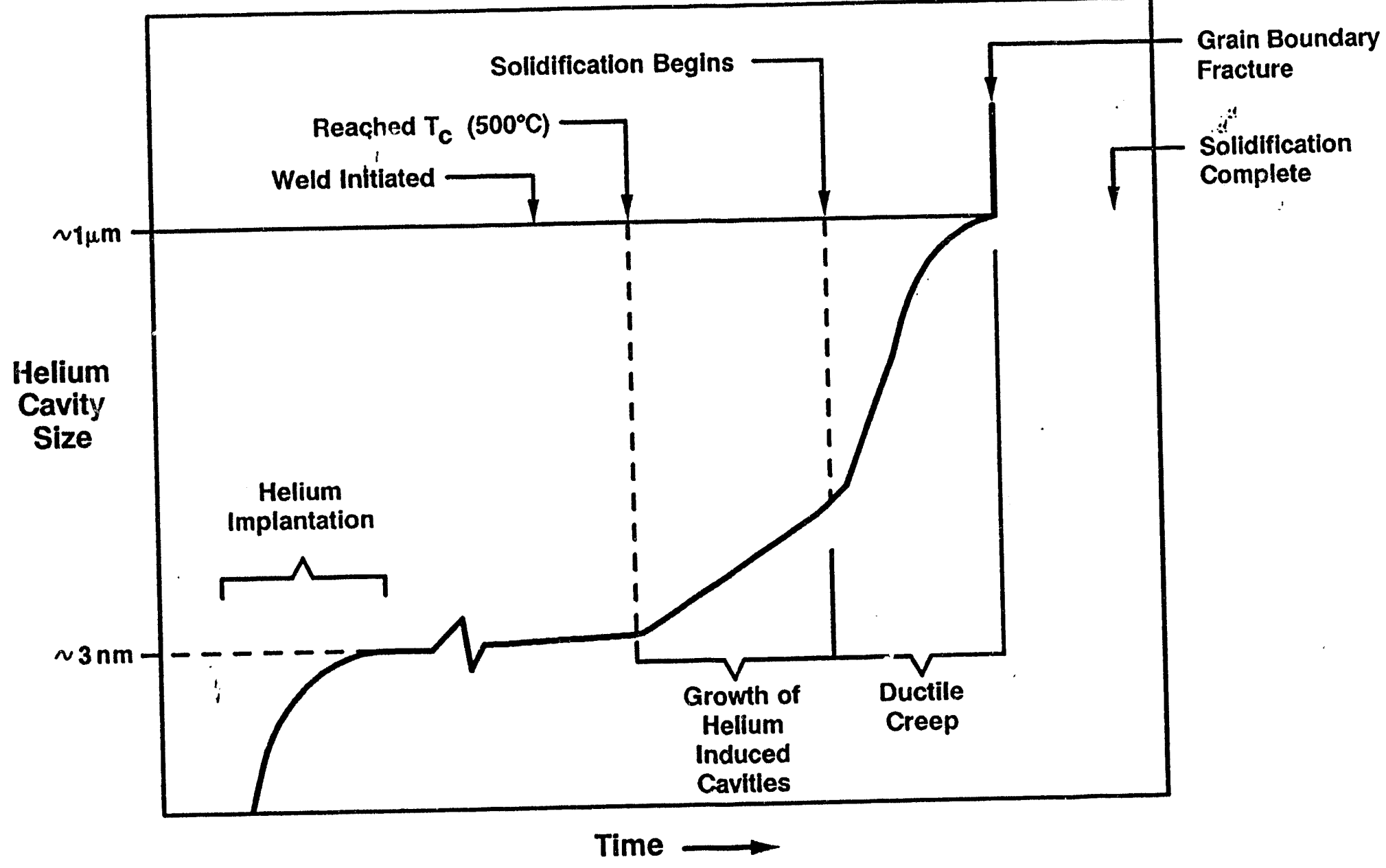

$$
F / 6,1
$$


$\tau \cdot 9 /=1$

9
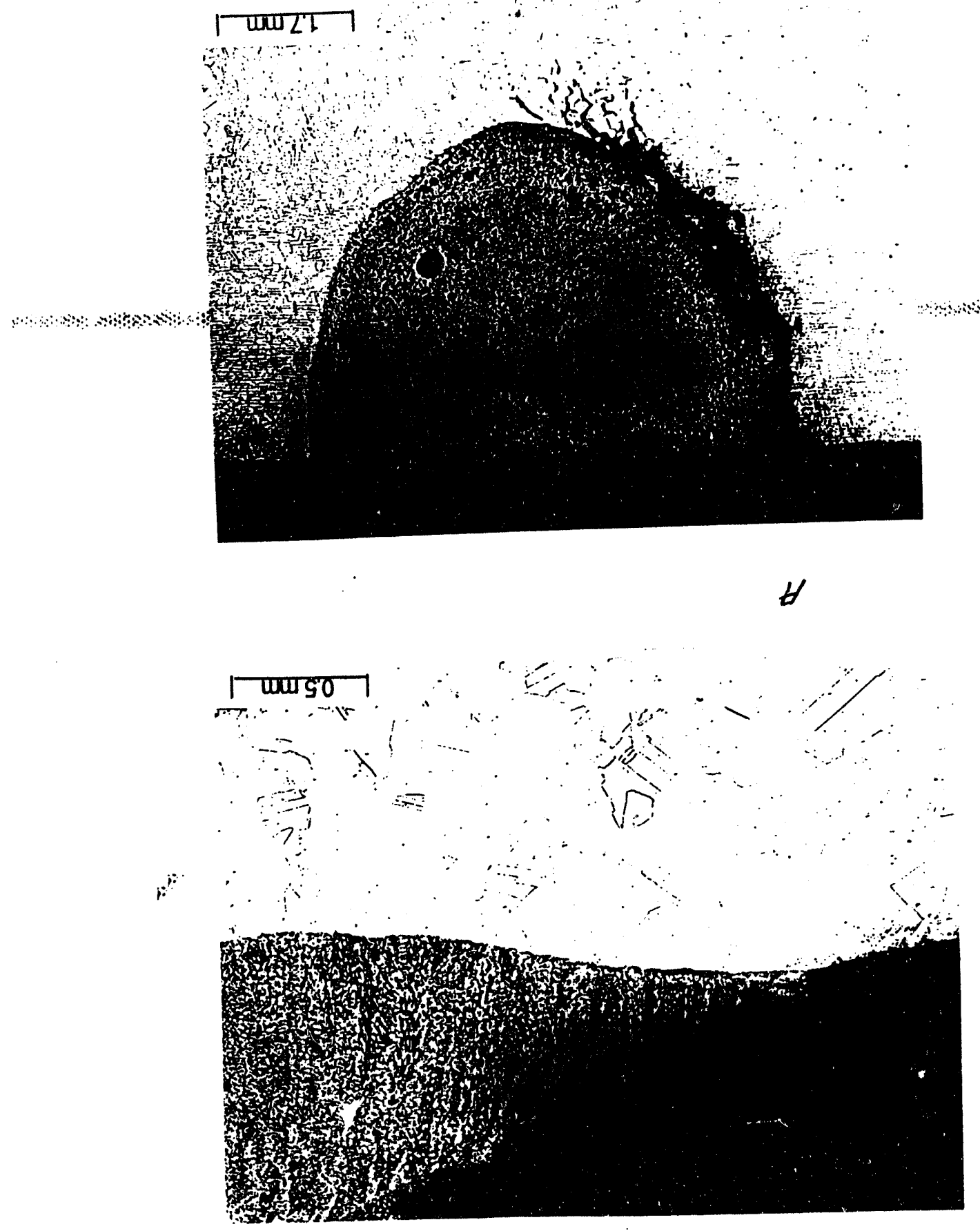


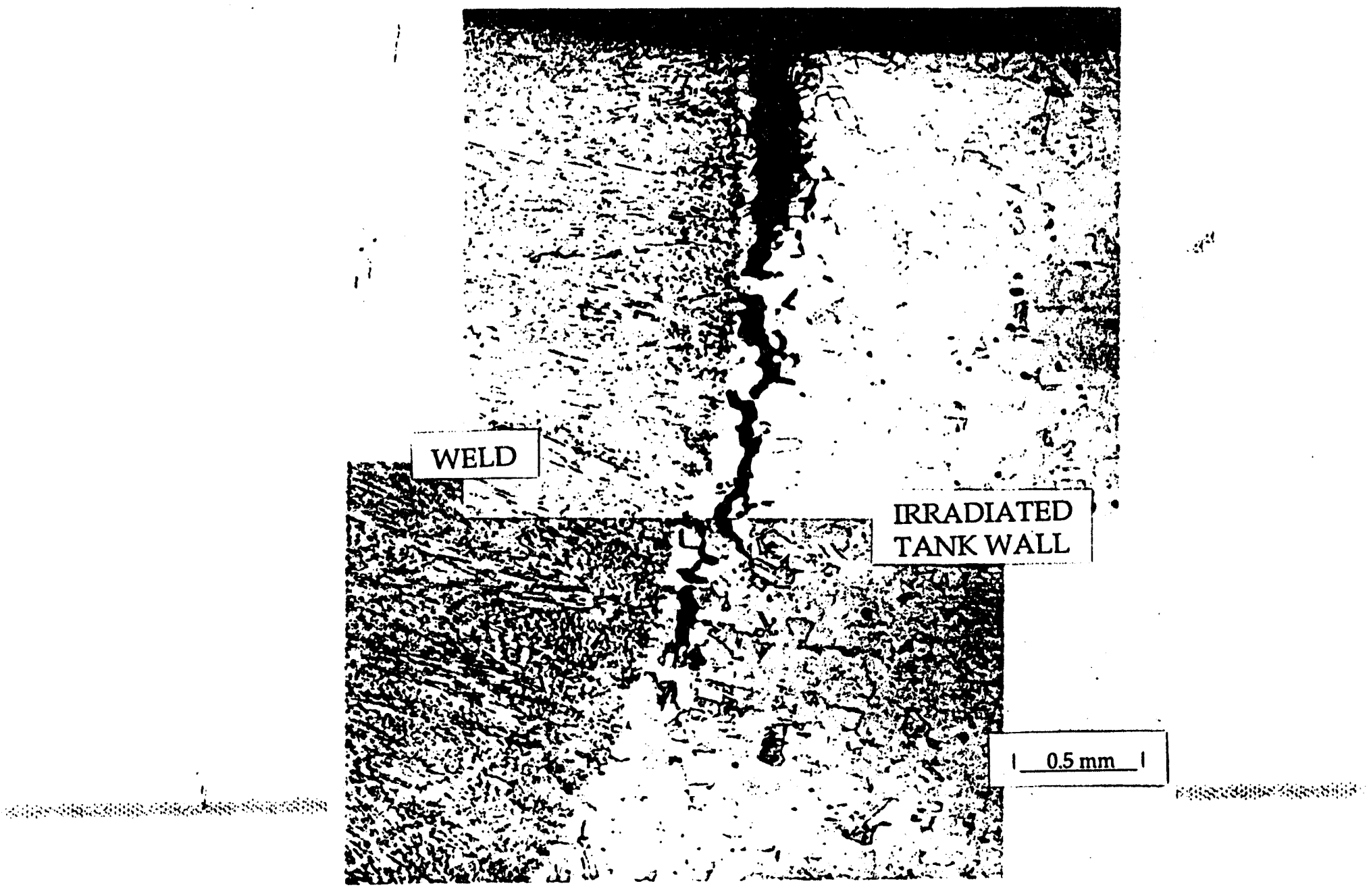

F 16.3 


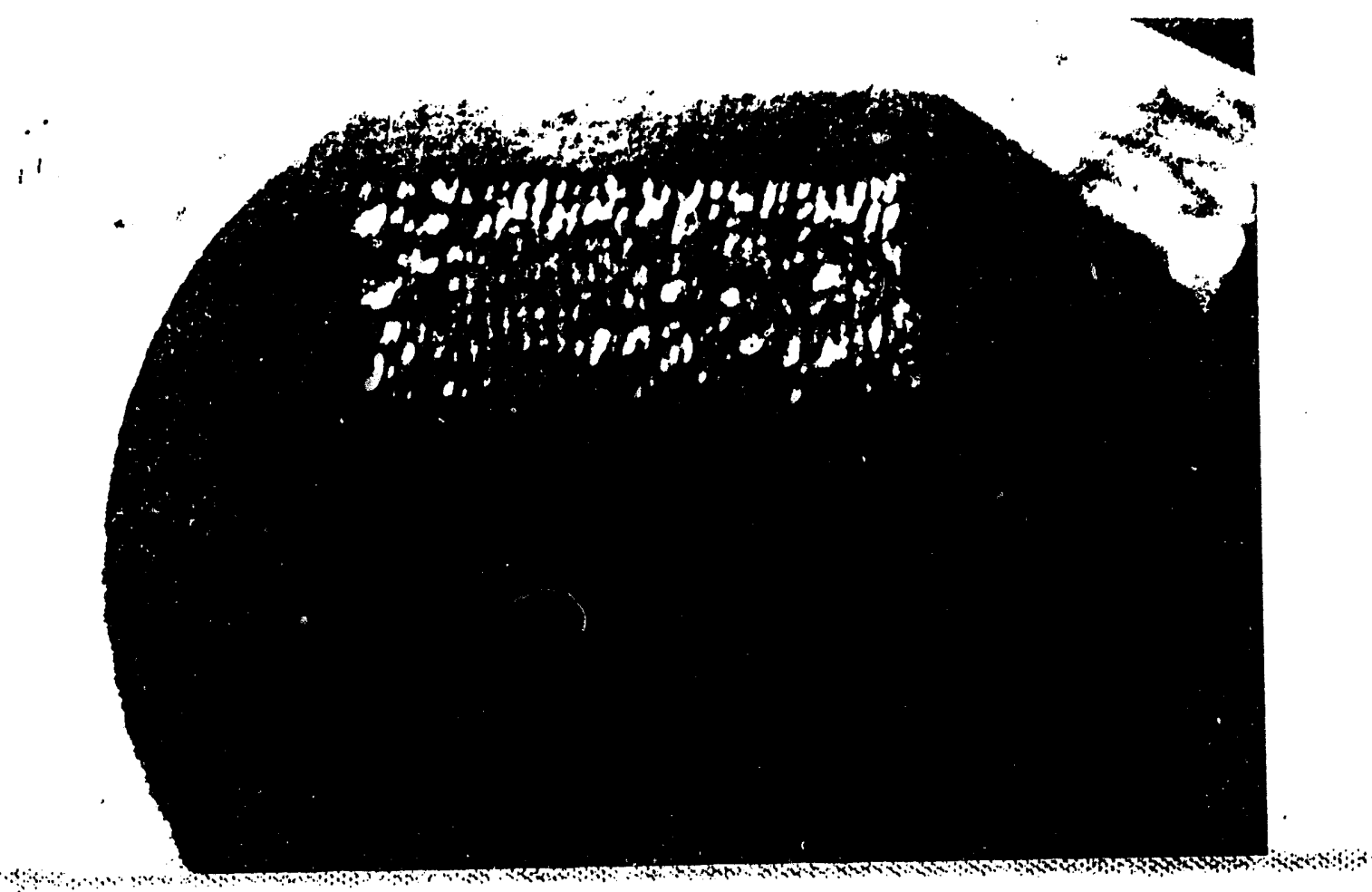

$$
\text { F 16. } 4
$$



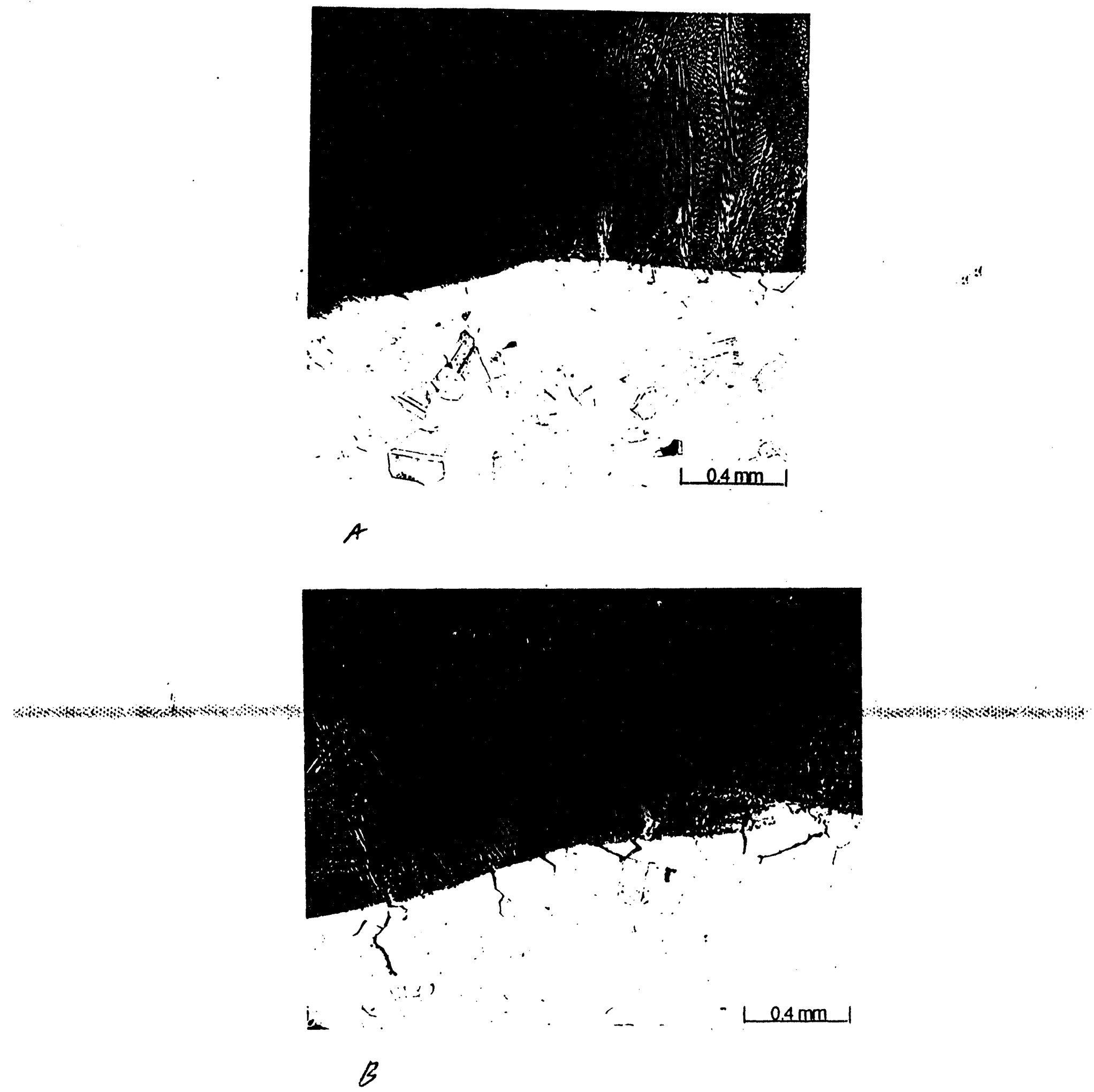

F16. 5 


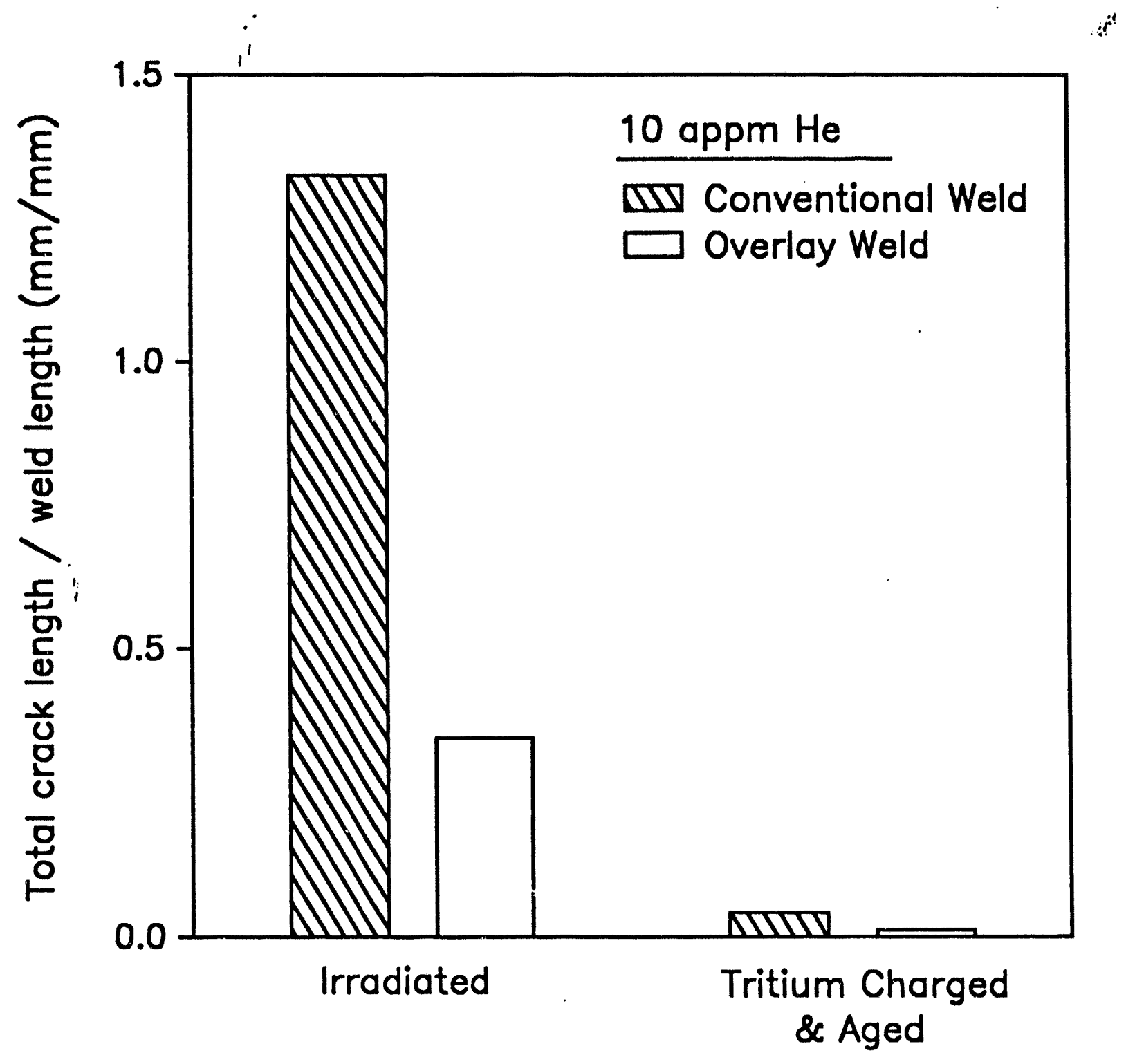

Fio. 6 

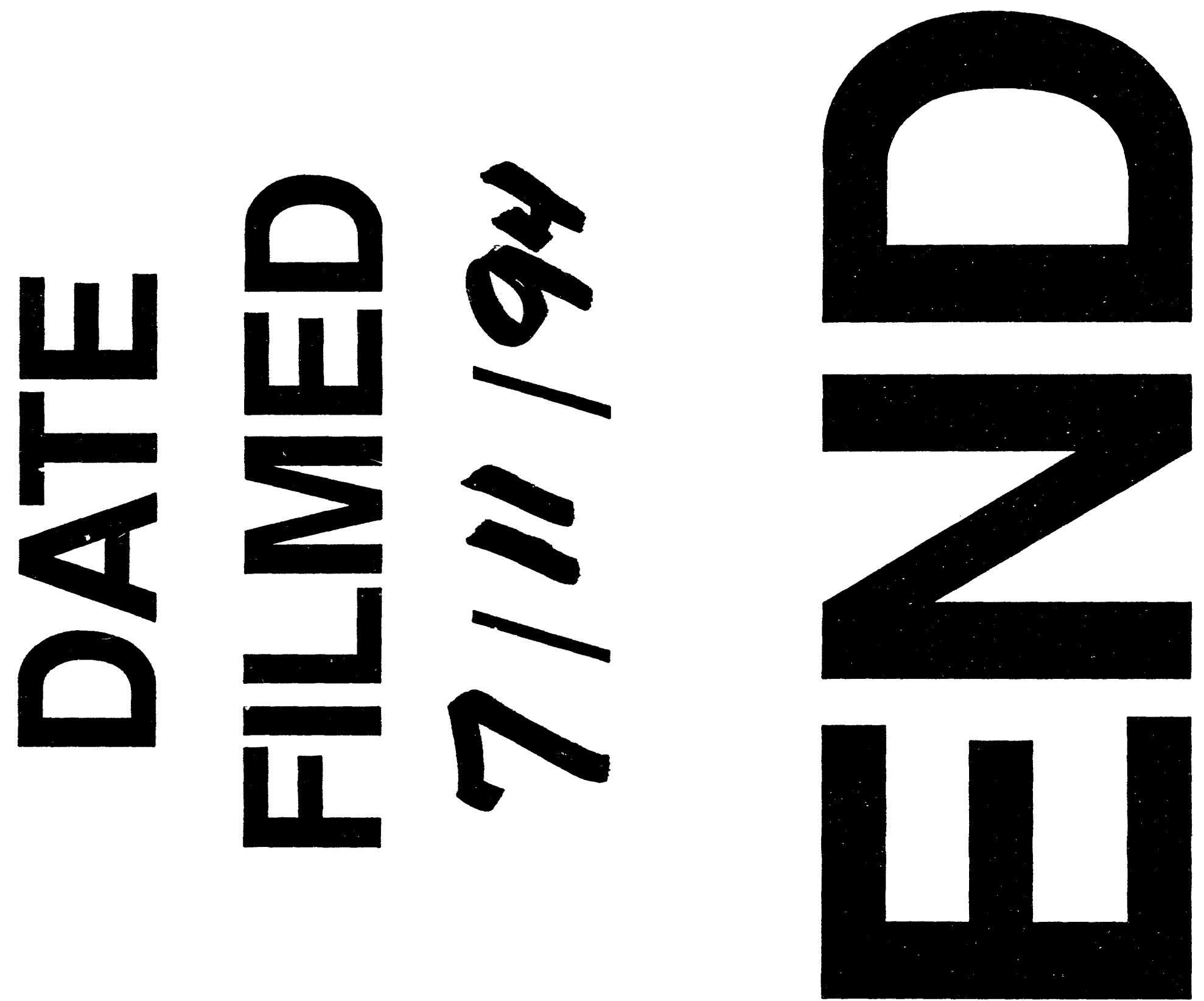
